\title{
Integration of Health Education and Cultural Value of Bimanesse Called "Maja Labo Dahu" toward the Intention to Stop Smoking of Smoker Student at Bima District-Indonesia
}

\author{
Martiningsih $^{1}$, Nurul Inayati ${ }^{2}$, Rini Hendari ${ }^{1}$, Ade Wulandari ${ }^{1}$ \\ ${ }^{1}$ Mater of Science Nursing, Department of Medical Surgery Nursing Department, Mataram Health Polytechnic \\ (Poltekkes Mataram), Bima 84112, West Nusa Tenggara-Indonesia, ${ }^{2}$ Master of Health Analyst, Mataram Health \\ Politechnic (Poltekkes Mataram), Mataram 83232, West Nusa Tenggara-Indonesia
}

\begin{abstract}
Socio-cultural elements may affect someone to follow or leave a behavior. Cultural values in the Bima District-West Nusa Tenggara Province community that are in line with health behavior are the cultural values called "Maja Labo Dahu/MLD", "Maja" means self-aware and "dahu" means carefulness. This study aims to determine the effect of integrating the cultural value of "MLD" and health education toward the intention of high school student to stop smoking in Bima district. This study is a quasy experiment with pre-post-test with control group design with purposiv sampling on 60 students of 5 Senior High School in Bima district. Self report was used to analyze the intention to stop smoking. Data analysis was examined by using Pairred T-Test. The results showed $86.7 \%$ had strong intention to stop smoking and $13.3 \%$ had weak intention. The mean standard pre-post deviation in the treatment group was 4,633 $\pm 8,046$ with a p-value $<0.001$. It can be concluded that there was a significant effect of interventions integrating MLD cultural values and health education toward the intention of student to stop smoking. Therefore, "Smoking session" efforts are required by considering elements of local culture and family resources.
\end{abstract}

Keywords: Education, Cultural Values, Intention to Stop Smoking.

\section{Introduction}

The overview Smoking behavior of adolescents in our country is very worrying. One-fifth of Indonesia's population aged between 13-15 years have smoked and have tried cigarettes for the first time at the age of less than 10 years. Three out of five Indonesian students aged 13-15 have been exposed to cigarette advertisements and can easily buy cigarettes ${ }^{1}$. In the world, smoking is the highest cause of death and disability, because smoking

\footnotetext{
Corresponding Author:

Martiningsih

Mataram Health Polytechnic (Poltekkes Mataram),

Prodi Keperawatan Bima, Jl. Soekarno Hatta 03-84112,

Bima-West Nusa Tenggara-Indonesia

e-mail: ningthahir@gmail.com

Phone Number: 081237327111
}

is the main behavioral risk factor associated with Cerebro Vascular Desease (CVD) besides hypertension, unhealthy diets, high cholesterol and air pollution ${ }^{2}$. Based on this, it is important for the government to try to stop the increase in new smokers/prevent the addition of new smokers if we want to reduce the number of teenage smoking and educate the younger generation about the effects/dangers of smoking.

It is important to make collaboration in order to educate young people such as students. The government through the Ministry of Health of the Republic of Indonesia with the youth health program has made various efforts but needs to be supported by various parties. The research suggests the need to promote health prevention of early smoking behavior among adolescents including involving the school. This becomes the basis for the need for literacy to bring up the intention to stop smoking for adolescents who have/just started smoking ${ }^{3}$. In line with research on high school students in the district of Bima, 
the number of high school students who smoke is around $15 \%$ of the population. This figure is quite high besides it confirmed by the fact that the majority of teenagers start smoking since junior high school/junior high school and even elementary school/elementary school ${ }^{4}$. Therefore prevention of risk behavior and changing risk behavior into health-supporting behavior through education, especially for adolescents/adolescence, is important in the long-term preventive effort that is sustainable and synergizes with programs that support health and consider the elements of local cultural values.

Bimanesse society define culture as something that is associated with behavior, in this case health behavior is the cultural value of "Maja LaboDahul MLD”. MLD cultural value contains two components which are interrelated and complementary ${ }^{5}$. Based on this, this study was conducted to analyze the effect of the integration of health education and the cultural value of Bimanesse culture "Maja Labo Dahu" on the intention to stop smoking in high school student smokers.

\section{Materials and Method}

This research was a quasi-experimental conducted in the district of Bima West Nusa Tenggara Province in August-September 2019. The respondents were the 10-12 grader of high school students from 3 state high schools, 1 vocational high school, 1 madrasa aliyah (Islamic high school) and the sample selection was purposive sampling with a total of 60 respondents divided into two groups. The treatment group was given health education using a booklet entitled "Self Confidence and Achievement without Smoking" which contained the integration of health eduaction about the health hazards of smoking and the cultural value of MLD (ISBN 978-623-91626-7-2) while in the control group provided health education using the booklet of the Ministry of Health of the Republic of Indonesia in 2017 entitle "Healthy Living without Cigarettes". Health education in each group was carried out for 4 meetings ( 1 meeting/week). The evaluation of quit smoking intention variables used quitting intention questionnaire and self report on smoking behavior. The research instrument consisted of 24 question items on the Linkert scale and validity and reliability tests were conducted. The results of the validity of the quitting intention questionnaire used in this study were $0.855>0.4227$ with a Cronbach's Alphareability test value of 0.734 . Processing and data analysis used SPSS 16 software with pairred T Test.

\section{Results and Discussion}

Results: Characteristics all respondents were male as many as 60 people (100\%) from locations in 5 High Schools (SMA). The others variables can be seen in the table below:

Table 1. Characteristics of age and Risk Factor CVD Based on history of Alcohol use and family smoker Based on Groupbased on group $(n=60)$

\begin{tabular}{|l|c|c|c|c|}
\hline \multirow{2}{*}{ Characteristics } & Treatment group (n=30) & \multicolumn{2}{|c|}{ Control group (n=30) } \\
\cline { 2 - 5 } & $\mathbf{n}$ & $\mathbf{\%}$ & $\mathbf{n}$ & $\mathbf{\%}$ \\
\hline Age, year & & & & \\
15 & 8 & 26.7 & 4 & 13.3 \\
16 & 15 & 50.0 & 12 & 40.0 \\
17 & 6 & 20.0 & 12 & 40.0 \\
18 & 1 & 3.3 & 2 & 6.7 \\
\hline Age; mean standard deviation, min-max, median (year) & 16 & 0.79 & $15-18$ & 16 \\
\hline Do you have family member that is addicted of smoking? & & & & \\
No & 15 & 50 & 14 & 46.7 \\
Yes & 15 & 50 & 16 & 53.3 \\
\hline
\end{tabular}

Based on the data in table 1 all respondents with an average age of 16 years (age range 15-18 years). CVD risk in the treatment group: based on alcohol use behavior $30 \%$ had tried and used alcohol and $53.3 \%$ had families smoked. 
Table 2. The intension of quitting of smoking before and after giving education on treatment and control group $(n=60)$

\begin{tabular}{|l|c|c|c|c|c|c|c|c|}
\hline \multirow{2}{*}{ Variabel } & \multicolumn{4}{|c|}{ Treatment group (n=30) } & \multicolumn{4}{c|}{ Control group (n=30) } \\
\cline { 2 - 9 } & \multicolumn{2}{|c|}{ Pre } & \multicolumn{2}{|c|}{ Post } & \multicolumn{2}{c|}{ Pre } & \multicolumn{2}{c|}{ Post } \\
\cline { 2 - 9 } & $\mathbf{n}$ & $\mathbf{N}$ & $\mathbf{N}$ & $\mathbf{\%}$ & $\mathbf{n}$ & $\mathbf{\%}$ & $\mathbf{n}$ & $\mathbf{\%}$ \\
\hline The intension to quit of smoking & & & & & & & & \\
Less & 12 & 40 & 4 & 13.3 & 14 & 46.7 & 9 & 30 \\
Good & 18 & 60 & 26 & 86.7 & 16 & 53.3 & 21 & 70 \\
\hline
\end{tabular}

Based on table 2. in the treatment group before MLD education showed that 12 people (40\%) had less intention to stop smoking and 18 people $(60 \%)$ had good smoking cessation intentions whereas after MLD education there were still $4(13.3 \%)$ with intention to quit smoking less smoking and 26 people $(86.7 \%)$ with good smoking cessation intentions.

Table 3. Distribution of mean the intension quit smoking of smoker student before and after giving education on treatment and control group in DISTRICT of Bima $(n=60)$.

\begin{tabular}{|l|c|c|c|c|c|}
\hline The intension quit smoking & Mean,SD & Min-Max & Mean pre-post, SD & 95\% CI & p-value \\
\hline Treatment Group & & & & & \\
- Pre & $76.27 \pm 5.452$ & $65-88$ & & & \\
- Post & $80.85 \pm 6.063$ & $60-90$ & $4.633 \pm 8.046$ & $78.47-83.00$ & $<0.001$ \\
\hline Control Group & & & & & \\
- Pre & $76.21 \pm 6.772$ & $63-88$ & & $73.81-78.61$ & \\
- Post & $80.73 \pm 6.379$ & $56-91$ & $4.467 \pm 6.425$ & $78.59-83.11$ & 0.005 \\
\hline
\end{tabular}

Based on table 3 , it shows that the difference in the mean of the first and second measurements in the treatment group is 4,467 with a standard deviation of 8.046. The $\mathrm{p}$-value is $<0.001$, so it can be concluded that there is a significant difference between pre and post education measurements in groups that get health education integrated with MLD cultural values.

\section{Discussion}

In this study, risky behavior in intervened adolescents is smoking behavior by integrating the cultural values of MLD and health education "No smoking" so that it is expected that adolescents have the knowledge and awareness which further becomes a stimulus and has a strong intention to stop smoking. Findings The results of this study indicate that integrated health education with local cultural values in this case MLD cultural values have a significant influence on the strong intention to stop smoking in high school students in the district of Bima. This study is as relatively same as the results of Herawati, et al., 2017 research which suggests the need for health promotion of adolescents who have/just started smoking. Thus, it is the basis for the need of literacy to bring up the intention to quit smoking. In line with the research of Akmal, et al., 2016 in high school students in the district of Bima entitle "Attitudes Influencing the Intention to Stop Smoking in High Schools students in the district of Bima" which suggest the need some efforts to prevent risk behaviors or change risk behaviors into health-supporting behaviors including through education especially in adolescents/adolescence. This becomes important in the long-term preventive efforts that continue to be sustainable and synergize with programs that support health and consider local cultural value elements.

The results of the bivariate analysis of the intention to quit smoking before the MLD education of adolescents with the intention to quit smoking less as much as $40 \%$ while after the MLD education decreased to $13.3 \%$ compared to the control group before the education of adolescents with the intention to quit smoking less as much as $46.7 \%$ while after education decreased to $30 \%$. 
This shows that although there was a similar decline, there were more smokers in the treatment group who had stronger smoking cessation intentions than in the control group. This means that health education integrated with the local cultural value of "MLD" which is the cultural value of the Bimanesse society influences the emergence of intentions and increases motivation to quit smoking. In accordance with the results of research that a person will follow or leave a behavior influenced by sociocultural elements and a strong intention to stop smoking is influenced by subjective norms that are believed by individuals ${ }^{4}$.

Based on the Big Indonesian Dictionary/KBBI published by the Ministry of National Education, being ashamed means feeling very uncomfortable (despicable, inferior, etc.) for doing something that is not good (not right, different from the habit) and afraid that can be interpreted as piety; reluctant, not brave (doing something that is not appropriate ${ }^{6}$. The meaning according to KBBI is in line with the meaning of the word MLD in the Bimanesse society. The word "Maja" means shame and "Dahu" means Afraid. If we review the above words semantically or meaningfully, "Maja" (shame) means that people or people of Bima will be ashamed when doing something outside of God's corridor, whether it is crime, sin, etc. whether related to humans or to God. "Dahu" (afraid), almost have the same interpretation process as the word Shame. Equally afraid when committing a crime or badness. In adolescent smokers who get integrated health education states that education with a health hazard approach to the effects of smoking alone is not enough to sensitize because of a sense "Excessive confidence" in his health status and adolescent age, so an additional approach cultural values as general values that apply in social life and society are more easily accepted and obeyed.

Characteristics of smoking behavior in this study $83.3 \%$, were active smokers in the last 6 months with the age of the firstly smoking started at the age of 10 years -14 years and $16.7 \%$ started smoking at the age of less than 10 years. This is consistent with the results of research related to smoking behavior in Indonesia according to the Global Youth Tobacco Survey/GYTS, (WHO, 2015) that every year there are 16.4 million new smokers age between 10 and 19 years. So efforts to reduce the number of teenage smokers, prevent new smokers and educate young people about the effects and dangers of smoking are very important to save Indonesia's future generations from cardiovascular epidemics ${ }^{7}$. The age of first smoking at the age of 1618 years, significantly increases the risk of the incidence of hypertension independently (people who smoke for the first time at the age of 16-18 years will immediately become regular smokers, ie people who smoke at least 1 cigarette/days, not smoking anymore as a trial and error. According to the results of research that shows that as much as $51.3 \%$ of CVD sufferers mostly start smoking at the age of adolescents. Based on these findings it is necessary to implement policies to promote healthy lifestyles in children and adolescents is very important for the prevention of CVD Healthy behavior is learned from childhood and continues into adulthood ${ }^{8}$.

In addition, it is necessary to strive to increase the role of the government in carrying out a strategy of cultural approach that is safe and acceptable to the community ${ }^{9}$ and working with educational institutions and increasing the accessibility of adolescents to health promotion programs carried out using community approaches in educational institutions that proven to have a positive effect on changes in adolescent health behaviors ${ }^{10}$. The results of other studies indicate that Fear and Embarrassment or "Maja Labo Dahu" are values that need to be integrated in Education teaching materials. This will complement each other's successful educational process in schools ${ }^{5}$. In the end all of the above efforts are expected to have a positive effect with changes in adolescent health behavior.

\section{Conclusion}

Integrated the cultural values "MLD" and health education about the dangers of smoking affect the strong intention to stop smoking in high school students. Integrated and programmed education based on local cultural values in high school as an effort to initiate the intention to quit smoking influences giving stronger stimulation to increase smoking cessation intention so as to then can encourage efforts to to Intention Quit Smoking and avoid risky behavior among adolescents. Continued efforts are needed in the literacy of the prevention of smoking behavior in adolescents at an earlier age level (elementary school and junior high school) taking into account local cultural elements and the resources available at school.

Acknowledgement: Acknowledgments for the advice and input of the expert team of the Health Polytechnic research unit of the Ministry of Health of Mataram and to all those who have contributed morally and materially, which we are really appreaciated. 
Source of Funding: This research supported by financial assistance from the Ministry of Health PPSDM RI through the Ministry of Health of the Health Polytechnic of Mataram.

Ethical Consideration: This study has received Ethical approval from the Mataram University Health Research Ethics Committee No: 207/UN18.8/ $\mathrm{ETIK} / 2019$.

\section{Conflict of Interest: Nil}

\section{References}

1. WHO. (2015). Global Youth Tobacco Survey (GYTS): Indonesia report 2014. Who-Searo. https://doi.org/http://www.searo.who.int/tobacco/ documents/ino_gyts_report_2014.pdf

2. Thomas, H., Diamond, J., Vieco, A., Chaudhuri, S., Shinnar, E., Cromer, S.,Moran, A. E. (2018). Global Atlas of Cardiovascular Disease 20002016: The Path to Prevention and Control. Global Heart, 13(3), 143-163. https://doi.org/10.1016/j. gheart.2018.09.511

3. Herawati, L., Budiman, J. A., Haryono, W., \& Mulyani, W. (2017). Jayapura Teenagers Smoking Behavior. Journal of Community Health, 42(1), 78-82. https://doi.org/10.1007/s10900-016-0232-4

4. Dzul Akmal, Bagoes Widjanarko, P. N. (2017). Sikap Mempengaruhi Niat Berhenti Merokok pada Remaja SMA di Kota Bima, 12.
5. Departemen Pendidikan Nasional. (2008). Kamus Bahasa Indonesia. Departemen Pendidikan Nasional. Jakarta.

6. Tan YL. and Dorotheo U. (2018). The Tobacco Control Atlas: ASEAN Region, Fourth Edition, September 2018. Southeast Asia Tobacco Control Alliance (SEATCA), Bangkok. Thailand.https:// seatca.org/dmdocuments/SEATCA/2018.pdf

7. Mendis, S., Puska, P., Norrving, B., (2011).Global Atlas on Cardiovascular Disease Prevention and Control. World Health Organization, Geneva 2011. https://www.ncbi.nlm.nih.gov/pubmed/30301680. DOI:10.1016/j.gheart.2018.09.511

8. AN Maulidya, D Ayuningtyas (2018). Availability, Accessibility, And Acceptability of Health Services In Remote Indigenous Community of the Baduy Dalam Tribe. Indian Journal of Public Health Research \& Development 9 (12), 513-518

9. Minary L, Cambon L, Martini H, et al. Efficacy of a smoking cessation program in a population of adolescent smokers in vocational schools: a public health evaluative controlled study. BMC Public Health. 2013;13:149. Published 2013 Feb 18. doi:10.1186/1471-2458-13-149.

10. Munir, A. (2018). Integrasi nilai-nilai budaya bima dalam bahan ajar pendidikan islam, 329-340. 